\title{
Aplikasi Pupuk NPK Dan Bokashi Serta Interaksinya Terhadap Pertumbuhan Dan Produksi Tiga Varietas Ubi Kayu (Manihot escculenta. L) Di Kutai Timur
}

\section{NPK And Bokashi Fertilizer Application And Its Interaction To The Growth And Production Of Three Cassava Varieties (Manihot escculenta. L) In Kutai Timur}

\author{
Ratna Shanti ${ }^{1}$ dan Ratna Nirmala ${ }^{1}$ \\ ${ }^{1}$ Tenaga Pendidikan Program Studi Agroteknologi, Fakultas Pertanian, Universitas Mulawarman Jl. Pasir Balengkong \\ Kota Samarinda, Kalimantan Timur 75117 \\ email : ratnasanti.msi@gmail.com,ratnanirmala1948@yahoo.co.id
}

Diterima : 17 Mei 2017 Disetujui : 20 Juni 2017

\begin{abstract}
The purpose of this study to determine the effect of fertilization on the production of three varieties of cassava that is Darul Hidayah, Gajah and Varietas Local. The field experiment was conducted for 9 months starting from April to December 2016. Locations trial in Sangata Selatan, DistrictKutai Timur.The design is split plot design arranged in a factorial treatment was repeated 3 times $(R)$ Treatment Varieties $(V)$ as the main plots and fertilizer treatments $(P)$ as subplot. The results showed that the inorganik fertilizer (NPK), organik (Bokashi) and combinations thereof capable of producing tubers each, 124 tons per hectares, 130.44 tons per hectares, and 134.67 tons per hectares and 99.11 ton per hectares as a kontrol s. Fertilization treatment of three varieties cassava tubers can increase production 20\%. 23.8\% and 26\% respectively as a compared with kontrol s. While the tuber production between varieties Darul Hidayah and Gajah 148.50 tons perhectares and 132, 33 ton per hectares while the local variety 85.33 tons per hectares. The increase in the tubers from 3 varieties namely $42.5 \%$ and $35.6 \%$ compared to local varieties.
\end{abstract}

Keywords: anorganik and organik fertilizers, varieties of cassava

\section{PENDAHULUAN}

Ubi kayu (Manihot escculenta, L) merupakan salah satu tanaman pangan umbiumbian yang mudah dijual sebagai mata dagangan (cash crop). Disamping itu ubi kayu dapat diolah menjadi starch (pati) relatif tinggi, gaplek, tepung ubi kayu, etanol, gula cair, surbisol, monosodium glutamat, tepung aromatik, dan pakan ternak (pelet). Di Cina ubi kayu dapat dimanfaatkan sebagai bahan pembuat pakaian, bahan fiber,dan pulp. (Kymaryo, et al., 2000 dan Yi Bo, et al., 2010)

Mengingat Kalimantan Timur mempunyai potensi yang besar untuk mengembangkan tanaman ubi kayu sebagai sumber karbohidrat, gaplek, bahan baku bioetanol, maka berdasarkan uraian diatas Perhimpunan Persahabatan Indonesia-Tiongkok (PPIT) berinisiatif dan berprogram sebagai mediator agar Pemerintah Indonesia, khususnya Provinsi Kalimantan Timur dapat berperan sebagai pemasok (pensupply) bioenergi yang berasal dari komoditas ubi kayu (Manihot esculenta), sedangkan Pemerintah Tiongkok berperan sebagai konsumen dalam bentuk bahan baku setengah jadi (gaplek). Harapan kedepan PPIT bisa mengekspor keunggulan komparatif Sumber Daya Alam (SDA) Kalimantan Timur agar dapat menarik investor asing untuk berinvestasi di Kalimantan Timur untuk menangani industri hulu ke hilir dan juga meningkatkan dan pengembangan ekonomi kerakyatan yang pada sasarannya mensejahterakan masyarakat Kalimantan Timur.

Ubi kayu dapat digunakan sebagai bahan baku bioetanol sebagai pengganti BBM yang memiliki beberapa keunggulan dimana bioetanol sebagai campuran premium (gasohol), menghasilkan emisi gas buang yang lebih rendah sehingga lebih ramah lingkungan, karena kandungan oksigennya meningkatkan efisiensi pembakaran.

Sebagai tanaman pangan ubi kayu merupakan sumber karbohidrat tertinggi disamping jagung, beras dll. Di Indonesia menempati urutan ketiga setelah padi dan jagung. Sebagai sumber karbohidrat ubi kayu merupakan penghasil kalori terbesar dibandingkan tanaman lain (Arifin, 2005). Nilai kalori ubi kayu sebesar $250 \times 10^{3}$ jagung : $200 \times 10^{3}$ beras: $176 \times 10^{3} \mathrm{kal} / \mathrm{ha}$. Tergantung pada varietas ubi kayu, karena potensi dari masing-masing varietas ubi kayu ini beragam (Radjit, dan Prastiaswati, 2011).

Kalimantan Timur di dominasi oleh tanah ultisol, tanah ini mempunyai karakteristik kesuburan tanah relatif rendah, $\mathrm{pH}$ asam, unsur hara $\mathrm{N}, \mathrm{P}, \mathrm{K}$ rendah dan kandungan bahan organik sedikit, untuk meningkatkan hasil/produksi tanaman maka perlu pemberian pemupukan baik organik maupun anorganik.

Pupuk organik berperan memperbaiki sifat kimia tanah yaitu menambah ketersediaan unsur 
hara, sebagai "buffering capacity" mampu mencegah toksid sehingga tidak tersedia (Stevenson, 1982 dan Setyorini, 2005). Memperbaiki sifat fisik tanah yaitu memperbaiki struktur tanah, permeabilitas, pori-pori, meningkatkan air tersedia, meningkatkan agregat tanah. Selanjutnya memperbaiki sifat biologi tanah, meningkatkan aktivitas biologi tanah, meningkatkan bahan organik (Arinong, dan Lasiwa, 2011). Selain pupuk anorganik dikenal pula pupuk organik yaitu bokashi yang

\section{BAHAN DAN METODE}

Penelitian ini dilaksanakan selama 9 bulan yaitu mulai dari bulan April sampai dengan Desember 2016. Lokasi percobaan di lahan pertanian wilayah Kecamatan Sangatta Selatan, Kabupaten Kutai Timur. Bahan yang digunakan stek tanaman ubi kayu 3 macam varietas (1) Darul Hidayah, (2) Gajah dan (3) Lokal. pupuk yang digunakan adalah pupuk npk (phonska) dan pupuk organik (bokashi),dan bahan kimia. Penelitian dilakukan dengan menggunakan Rancangan Split Plot Design atau Rancangan Petak Terpisah dengan ulangan (R) 3 kali yang perlakuannya disusun secara faktorial yaitu perlakuan Varietas (V) sebagai Petak Utama dan perlakuan pupuk (P) sebagai Anak Petak. Petak utama adalah varietas ubi kayu yaitu : v1 $=$ Varietas local ; v2 = Varietas Darul Hidayah ; v3= Varietas Gajah. Anak petak adalah jenis pupukorganik dan pupuk anorganik NPK serta kombinasinya yaitu : p0 $=$ Tanpa

\section{HASIL DAN PEMBAHASAN}

\section{Hasil Analisis Sifat Kimia Tanah}

Berdasarkan hasil analisis tanah (Tabel 1) menunjukkan bahwa kemasaman tanah $(\mathrm{pH})$ sebelum dipupuk 3,85 setelah diberi perlakuan $\mathrm{pH}$ mengalami peningkatan antara 4,10 -4,79. Nilai $\mathrm{pH}$ terendah terjadi pada perlakuan pupuk anorganik (NPK) yaitu 4,10. Pemberian pupuk organik (bokashi) $\mathrm{pH}$ tanah menjadi 4,3 dan perlakuan kombinasi pupuk anorganik (NPK) dan organik (bokashi) pH- nya menjadi 4,79. Hal ini menunjukkan bahwa pemupukan meningkatkan $\mathrm{pH}$ tanah. Peningkatan $\mathrm{pH}$ tanah dari 3,85 menjadi 4,79 akibat pemupukan bokashi, yang mana bokashi ini mengandung pupuk kandang dan bahan organik yang difermentasi dengan efektif mikroorganisme.

Fermentasi ini akan menghasilkan glukosa, ester, asam nukleat, alkohol, ester, asam amino, hormone, enzim, vitamin dan antioksidan. Diduga hasil-hasil de-ionisasi ini akan mengikat ion $\mathrm{H}^{+}$sehingga konsentrasi ion $\mathrm{H}^{+}$menurun. didekomposi dengan bantuan Effective Microorganisms(EM) yang dapat memacu pertumbuhan tanaman karena menghasilkan zat pengatur tumbuh (ZPT). Disamping itu bahan organik dapat memperbaiki sifat kimia, fisik dan biologi tanah (Wididana dan Higa, 1993). Sehubungan dengan hal itu, tujuan penelitian ini untuk mengetahui pengaruh pemupukan terhadap produksi dari 3 varietas yaitu Darul Hidayah, Gajah dan Varietas Lokal

Pupuk (Kontrol); p1= Pupuk Anorganik (800 kg $\mathrm{NPK} / \mathrm{Ha}) ; \mathrm{p} 2=$ Pupuk Organik $(20.000 \mathrm{~kg}$ Bokashi/Ha); p3: Kombinasi PupukAnorganik (800 kg NPK/Ha + Pupuk Organik (20. 000 kg Bokashi/Ha). Pelaksanaan penelitian meliputi pembersihan lahan, pengolahan tanah, pembuatan bedengan dengan ukuran $300 \mathrm{~cm} \mathrm{x}$ $400 \mathrm{~cm}$, dan tinggi $30 \mathrm{~cm}$ dengan jarak antar bedengan $100 \mathrm{~cm}$, pemupukan dilakukan sesuai dengan perlakuan setiap petak yaitu 800 gram /petak dan bokhasi $50 \mathrm{~kg} /$ petak serta kombinasinya yaitu 800 gram NPK dan bokashi $50 \mathrm{~kg} /$ petak, jarak tanam $75 \mathrm{~cm} \mathrm{X} 75 \mathrm{~cm}$ Panjang stek $20 \mathrm{~cm}$. Stek ditanam tegak lurus sedalam 5-10 Cm, Pemeliharaan: penyiraman, penyulaman, penyiangan dan pembumbunan dan panen umbi dilakukan setelah tanaman berumur 9 bulan. Pengambilan data meliputi : data tanah (sifat kimia tanah) $\mathrm{pH} \mathrm{H}_{2} \mathrm{O}$ dan $\mathrm{pH} \mathrm{KCl}, \mathrm{N}$ total, $\mathrm{P}$ dan $\mathrm{K}$ tersedia, $\mathrm{C}$ - organik dan jaringan daun tanaman, Data tanaman : tinggi tanaman, berat umbi per hektar, biomasa per hektar.

Hal ini akan mengakibatkan konsentrasi ion $\mathrm{OH}^{-}$meningkat atau $\mathrm{pH}$ tanah meningkat pula. Kemasaman tanah ini lebih sesuai dengan kebutuhan $\mathrm{pH}$ optimum bagi pertumbuhan ubi kayu yaitu 5,8. Karbon organik pada tanah sebelum perlakuan (tanah awal) 1,76 persen. Setelah perlakuan pemupukan mengalami peningkatan menjadi 1,77 - 2,16 persen. Nitrogen $(\mathrm{N})$ total pada tanah awal 0,13 persen setara dengan $26 \mathrm{~kg} \mathrm{~N}$ per hektar. Sedangkan kebutuhan tanaman ubikayu terhadap unsur $\mathrm{N}$ sebesar $90 \mathrm{~kg}$ per hektar, sehingga kekurangan sebesar $64 \mathrm{~kg}$. Jumlah ini dapat dipenuhi dengan jumlah pupuk (anorganik atau organik) yang diberikan.Hal ini ditunjukkan oleh data bahwa perlakuan pemupukan anorganik (NPK) dan organik (bokashi) meningkatkan ketersediaan nitrogen dari 0,14 hingga 0,26 persen setara dengan $28 \mathrm{~kg} \mathrm{~N}$ hingga $52 \mathrm{~kg} \mathrm{~N}$ per hektar. 
Berdasarkan data hasil analisis tanah terhadap unsur dalam tanah fosfor $(\mathrm{P})$ yang tercantum pada Tabel 1 menunjukkan bahwa $\mathrm{P}_{2} \mathrm{O}_{5}$ meningkat dalam tanah setelah pemeberian pupuk anorganik ataupun organik. Kandungan $\mathrm{P}_{2} \mathrm{O}_{5}$ dalam tanah sebesar 8 ppm setara dengan $18,2 \mathrm{~kg}$ fosfor per hektar. Sedangkan kebutuhan fosfor untuk tanaman ubikayu sebesar $200 \mathrm{~kg}$ per hektar. Pemberian pupuk organik dan anorganik serta kombinasinya meningkatkan fosfor dalam tanah. Fosfor dalam tanah setelah panen setelah panen berkisar antara $17-83 \mathrm{ppm}$ setara dengan 38,6 hingga 188,4 kg fosfor per hektar.
Sesuai dengan pendapat Nurhayati Hakim dkk, (1986), melalui proses pelapukan fosfor organik dapat diubah menjadi fosfor anorganik seperti $\mathrm{H}_{2} \mathrm{PO}_{4}{ }^{-}$dan $\mathrm{HPO}_{4}{ }^{=}$melaui proses pelapukan sehingga dapat diserap tanaman. Peran fosfor dianggap sebagai "key of life" pada tanaman karena mempunyai fungsi penting dlam proses foto sintesis, respirasi, transferenergy seperti adenosine trifosfat (ATP) dan adenosin difosfat (ADP), penyimpanan enersi, pembelahan dan pembesaran sel serta proses-proses didalam tanaman lainnya (Rosmarkun dan Yuwono, 2002).

Tabel 1. Analisis sifat kimia tanah

\begin{tabular}{|c|c|c|c|c|c|c|c|c|c|c|c|c|c|}
\hline \multirow{2}{*}{$\begin{array}{l}\text { Kode } \\
\text { Lap. }\end{array}$} & \multirow{2}{*}{$\mathrm{pH}$} & $\mathrm{OC}$ & N-total & \multirow{2}{*}{$\mathrm{C} / \mathrm{N}$} & $\mathrm{P} 2 \mathrm{O} 5$ & K2O & \multicolumn{2}{|c|}{$\begin{array}{l}\text { Kation } \\
\text { Asam }\end{array}$} & \multicolumn{4}{|c|}{ Kation Basa } & \multirow{2}{*}{ KTK } \\
\hline & & & $\%$ & & ppm P & ppm K & $\mathrm{Al}^{+3}$ & $\mathrm{H}^{+}$ & $\mathrm{Ca}^{++}$ & $\mathrm{Mg}^{+}$ & $\mathrm{K}^{+}$ & $\mathrm{Na}^{+}$ & \\
\hline Awal & 3,85 & 1,76 & 0,13 & 13 & 8 & 35 & 5,0 & 2,5 & 1,46 & 0,03 & 0,12 & 0,14 & 12,5 \\
\hline v1p1 & 4,10 & 1,81 & 0,15 & 12 & 17 & 56 & 3,5 & 1,5 & 2,32 & 0,50 & 0,16 & 0,14 & 12,1 \\
\hline v1p2 & 4,28 & 1,76 & 0,23 & 8 & 50 & 65 & 3,3 & 1,1 & 4,45 & 0,79 & 0,21 & 0,18 & 13,6 \\
\hline v1p3 & 4,65 & 2,16 & 0,15 & 14 & 80 & 62 & 1,2 & 1,3 & 6,48 & 1,16 & 0,19 & 0,22 & 15,0 \\
\hline $\mathrm{v} 2 \mathrm{p} 1$ & 4,12 & 1,79 & 0,14 & 13 & 20 & 25 & 3,6 & 1,8 & 2,35 & 0,56 & 0,14 & 0,14 & 11,8 \\
\hline $\mathrm{v} 2 \mathrm{p} 2$ & 4,30 & 1,77 & 0,23 & 8 & 52 & 24 & 3,4 & 1,0 & 4,54 & 0,68 & 0,22 & 0,24 & 14,0 \\
\hline $\mathrm{v} 2 \mathrm{p} 3$ & 4,79 & 2,15 & 0,14 & 15 & 81 & 18 & 1,0 & 1,4 & 6,86 & 1,22 & 0,20 & 0,17 & 15,8 \\
\hline v3p1 & 4,17 & 1,80 & 0,16 & 11 & 19 & 59 & 3,2 & 1,6 & 2,30 & 0,58 & 0,17 & 0,13 & 12,0 \\
\hline $\mathrm{v} 3 \mathrm{p} 2$ & 4,38 & 1,78 & 0,25 & 7 & 54 & 64 & 3,0 & 1,2 & 4,60 & 0,75 & 0,24 & 0,20 & 14,2 \\
\hline $\mathrm{v} 3 \mathrm{p} 3$ & 4,75 & 2,09 & 0,16 & 13 & 83 & 68 & 1,1 & 1,5 & 6,79 & 1,28 & 0,25 & 0,16 & 15,6 \\
\hline
\end{tabular}

Hasil dekomposisi bahan organik akan menghasilkan asam-asam organik dan $\mathrm{CO}_{2}$ disamping meningkatkan kandungan fosfor dalam tanah. Demikian pula Hadi Suwito (2007) yang menyatakan bahwa bahan organik yang sudah mengalami perombakan menjadi pupuk dapat menyediakan nitrogen bagi tanaman. Ditambahkan oleh Novizan (2005) nitrogen yang berasal dari bahan organik dapatdimanfaatkan oleh tanaman setelah terdekomposisi yang melibatkan aktivitas mikroorganisme tanah. Setyamidjaya (1986), nitrogen berperan untuk merangsang pertumbuhan vegetatif yaitu menambah tinggi tanaman membuat tanaman menjadi hijau karena banyak mengandung butir-butir hijau

\section{Hasil Analisis Jaringan Daun Tanaman}

Hasil analisis jaringan daun tanaman ubi kayu tercantum pada Tabel 2. Data hasil analisis jaringan daun tanaman ubi kayu tersebut (Tabel 2) menunjukkan bahwa antara tanaman yang dipupuk baik organik maupun anorganik serta kombinasinya dibandingkan dengan tanaman tidak dipupuk (kontrol), terdapat kecendrungan berbeda. Kandungan nitrogen pada tanaman yang tidak dipupuk (kontrol) sebesar 5,2 persen, sedangkan yang daun (khlorofil) yang penting dalam proses fotosintesis untuk pembentukan karbohidrat, protein dan lemak. Peranan unsur nitrogen apabila diserap oleh tanaman akan meningkatkan pembentukan asam amino dalam tanaman. Asam amino tersebut di ranslokasikan ke jaringan meristem untuk digunakan dalam pembelahan sel.

Hasil analisis unsur kalium $(\mathrm{K})$ dalam Tabel 1 menunjukkan bahwa $\mathrm{K}_{2} \mathrm{O}$ meningkat dalam tanah setelah pemberian pupuk bokashi dan NPK. Kandungan $\mathrm{K}_{2} \mathrm{O}$ meningkat dari 56-68 ppm setara dengan 112 - $136 \mathrm{~kg}$ kalium per hektar. Peningkatan kandungan kalium dalam tanah berasal dari pemupukan bokashi dan NPK.

dipupuk anorganik cenderung meningkat yaitu rata-rata sebesar 5,36 persen, dan yang dipupuk dengan pupuk organik meningkat rata-rata sebesar 5,5 persen. Hal ini disebabkan karena pemberian $\mathrm{N}$ ketersediaan $\mathrm{N}$ lebih tinggi sehingga absorpsi unsur tersebut cenderung lebih meningkat pula dalam proses metabolisme tanaman. Nitrogen diserap tanaman dalam bentuk $\mathrm{NO}_{3}^{-}$dan $\mathrm{NH}_{4}^{+}$ kemudian dirubah menjadi gugusan asam amino, 
selanjutnya membentuk protein dan asam nukleat. Dengan meningkatnya kandungan protein dalam protoplasma akan meningkatkan ukuran sel dan jaringan. Akibatnya tanaman akan tumbuh berkembang, dalam bentuk pertumbuhan vegetatif dan generatif yaitu masing-masing dalam bentuk akar, batang, daun dan umbi.

Tabel 2.Analisis jaringan daun ubi kayu

\begin{tabular}{|c|c|c|c|c|c|c|c|}
\hline \multirow{2}{*}{$\begin{array}{l}\text { Kode } \\
\text { Lapang }\end{array}$} & C-organik & N-total & \multirow{2}{*}{$\mathrm{C} / \mathrm{N}$} & $\mathrm{P}$ & K & $\mathrm{Ca}$ & $\mathrm{Mg}$ \\
\hline & \multicolumn{2}{|c|}{$\%$} & & \multicolumn{4}{|c|}{$\%$ total } \\
\hline v1p0 & 49,5 & 5,2 & 9,5 & 0,33 & 0,76 & 0,39 & 0,170 \\
\hline $\mathrm{v} 2 \mathrm{p} 0$ & 49,8 & 5,2 & 9,6 & 0,34 & 0,78 & 0,39 & 0,171 \\
\hline v3p0 & 50,3 & 5,3 & 9,5 & 0,34 & 0,78 & 0,39 & 0,171 \\
\hline v1p1 & 49,6 & 5,2 & 9,5 & 0,34 & 0,89 & 0,38 & 0,165 \\
\hline $\mathrm{v} 2 \mathrm{p} 1$ & 51,8 & 5,3 & 9,8 & 0,35 & 0,89 & 0,39 & 0,168 \\
\hline v3p1 & 52,2 & 5,4 & 9,7 & 0,35 & 0,90 & 0,40 & 0,169 \\
\hline v1p2 & 52,9 & 5,3 & 10,0 & 0,36 & 0,88 & 0,45 & 0,170 \\
\hline $\mathrm{v} 2 \mathrm{p} 2$ & 53,2 & 5,4 & 9,9 & 0,37 & 0,90 & 0,45 & 0,172 \\
\hline v3p3 & 53,8 & 5,5 & 9,8 & 0,37 & 0,90 & 0,45 & 0,173 \\
\hline v1p3 & 54,1 & 5,6 & 9,7 & 0,35 & 0,91 & 0,40 & 0,167 \\
\hline v2p3 & 54,5 & 5,6 & 9,7 & 0,35 & 0,92 & 0,40 & 0,169 \\
\hline v3p3 & 55,6 & 5,7 & 9,8 & 0,36 & 0,93 & 0,42 & 0,171 \\
\hline
\end{tabular}

Perbandingan C-N pada jaringan tanaman ubikayu menunjukkan angka 9,5 - 10. Hal ini menunjukkan bahwa kandungan nitrogen dalam jaringan daun cukup besar atau $\mathrm{C} / \mathrm{N}$ relatif rendah. Hal ini berarti ada korelasi antara kandungan nitrogen dalam tanah dengan kandungan nitrogen dalam jaringan tanaman dalam hal ini jaringan daun. Antara tanaman kontrol dan tanaman perlakuan pemupukan ternyata absorpsinya tidak berbeda, yaitu kontrol 0,34 persen dan tanaman yang diberi perlakuan pupuk anorganik dan organik 0,35 persen. Kemungkinan absorpsi unsur fosfor hanya mampu diabsorpsi sebesar 30 persen dari pupuk yang diberikan. Unsur fosfor lainnya dalam bentuk tidak tersedia yaitu difiksasi oleh koloid tanah/ mineral liat atau unsur $\mathrm{Al}$,atau $\mathrm{Fe}$. Fosfor diserap tanaman dalam bentuk $\mathrm{H}_{2} \mathrm{PO}_{4}^{-}$dan $\mathrm{HPO}_{4}^{-}$dan dirubah menjadi asam nukleat,fosfolipida dan fitin. Untuk tanaman ubikayu fosfor berperan untuk perkembangan akar. Selanjutnya akar tanaman ini berkembang menjadi umbi.

Hasil analisis jaringan tanaman (Tabel 2) menunjukkan bahwa absorpsi unsur kalium oleh tanaman ubi kayu yang diberi perlakuan pemupukan anorganik dan organik cenderung lebih tinggi $(0,89 \%)$ dibandingkan unsur kalium pada tanaman ubikayu yang tidak dipupuk $(0,77 \%)$. Hal ini disebabkan oleh karena unsur kalium pada tanah yang dipupuk anorganik dan organik ketersediaannya menjadi lebih tinggi atau melebihi kebutuhan optimal dari tanaman artinya ada korelasi antara absorpsi unsur kalium oleh tanaman dengan ketersediaannya dalam tanah. Unsur kalium berperan mendorong perkembangan sitoplasma dan sebagai katalisator dalam pembentukan karbohidrat, memperkuat batang dan perkembangan akar.

\section{Tinggi Tanaman}

Tabel 3.Interaksi antara dosis pupuk dan varietas terhadap tinggi tanaman ubi kayu $(\mathrm{cm})$

\begin{tabular}{cccc}
\hline Perlakuan & \multirow{2}{*}{ v2 } & v3 & Rata-Rata \\
\hline p0 (Kontrol) & 270,67 & 280,00 & 253,00 \\
p1 (NPK) & 281,67 & 298,00 & 274,22 \\
p2 (Bokashi) & 290,00 & 299,67 & 269,89 \\
p3 (Bokashi+NPK) & 298,33 & 307,00 & 274,78 \\
\hline Rata-Rata & 285,17 a & 296,17 a & 267,97 \\
\hline
\end{tabular}

Keterangan : Angka yang diikuti huruf yang sama menyatakan tidak berbeda nyata pada BNT 5\%.(BNT V = 24,57)

Dari hasil analisis statistik ( Tabel 3 dan 4) pada tinggi tanaman menunjukkan bahwa pupuk anorganik (p1- NPK) dan organik (p2- bokashi) serta kombinasinya(p3-NPK+bokashi) tidak berpengaruh nyata dibandingkan dengan kontrol (p0). Antara ketiga varietas tersebut 
yaitu ada kecendrungan tinggi tanaman ubi kayu varietas Gajah menunjukkan relatif lebih tinggi dibandingkan varietas Darul Hidayah dan varietas Lokal pada semua perlakuan. Pengaruh perlakuan pupuk anorganik dan organik (bokashi) serta kombinasinya pada tiga varietas ubikayu terhadap tinggi tanaman tercantum pada Tabel 3. Hasil analisis statistik interaksi antara dosis pupuk dan varietas terhadap tinggi tanaman ubi kayu tercantum pada Tabel 3, dan dapat digambarkan dalam bentuk kurva atau diagram batang atau histogram (Gambar 1).

Kemungkinan perbedaan tinggi tanaman disebabkan oleh sifat genetis tanaman, dimana tanaman ubikayu varietas lokal mempunyai fenotipe lebih pendek dari varietas yang lainnya.

Tabel 4. Pengaruh perlakuan pupuk anorganik dan organik serta kombinasinya terhadap tinggi tanaman saat panen pada tiga varietas ubi kayu $(\mathrm{cm})$

\begin{tabular}{ccccc}
\hline \multirow{2}{*}{ Varietas } & \multicolumn{3}{c}{ Ulangan (kelompok) } & \multirow{2}{*}{ Total } \\
\cline { 2 - 4 } & 1 & 2 & 3 & 625 \\
v1 (Lokal) & 200 & 217 & 208 & 729 \\
& 251 & 246 & 232 & 660 \\
& 230 & 230 & 200 & 657 \\
\hline \multirow{4}{*}{ v2 (Darul Hidayat) } & 252 & 198 & 207 & 812 \\
& 257 & 280 & 275 & 845 \\
& 268 & 247 & 330 & 870 \\
& 274 & 305 & 291 & 895 \\
\hline \multirow{2}{*}{ v3 (Gajah) } & 330 & 277 & 288 & 840 \\
& 307 & 263 & 270 & 894 \\
& 327 & 290 & 277 & 999 \\
\hline Total & 294 & 281 & 324 & 9647 \\
\hline
\end{tabular}

\section{Berat Umbi Per Hektar}

Tabel 5. Pengaruh perlakuan pupuk anorganik dan organik serta kombinasinya terhadap berat umbi per hektar pada tiga varietas ubi kayu (ton).

\begin{tabular}{cccccc}
\hline \multirow{2}{*}{ Varietas } & Perlakuan Pupuk & \multicolumn{3}{c}{ Kelompok } & \multirow{2}{*}{ Total } \\
\cline { 3 - 5 } & p0(kontrol) & 46,00 & 82,00 & 56,00 & 184 \\
v1(Lokal) & p1(NPK) & 74,00 & 110,00 & 92,00 & 276 \\
& p2(Bokashi) & 110,00 & 88,00 & 84,00 & 282 \\
& p3(Bokashi+NPK) & 92,00 & 102,00 & 88,00 & 282 \\
\hline \multirow{2}{*}{ v2 (Darul Hidayah) } & po(kontrol) & 124,00 & 110,00 & 102,00 & 336 \\
& p1(NPK) & 134,00 & 144,00 & 132,00 & 410 \\
& p2(Bokhasi) & 174,00 & 204,00 & 132,00 & 510 \\
& p3(Bokashi+NPK) & 218,00 & 172,00 & 136,00 & 526 \\
\hline \multirow{2}{*}{ v3 (Gajah) } & p0(kontrol) & 92,00 & 120,00 & 160,00 & 372 \\
& p1(NPK) & 140,00 & 130,00 & 160,00 & 430 \\
& p2(Bokhasi) & 106,00 & 114,00 & 162,00 & 382 \\
& p3(Bokashi+NPK) & 152,00 & 114,00 & 138,00 & 404 \\
\hline Total & & 1462 & 1490 & 1442 & 4394 \\
\hline
\end{tabular}

Keterangan : Angka yang diikuti huruf yang sama menyatakan tidak berbeda nyata pada BNT 5\% (BNT P = 46,89 dan BNT V = 18,95) 


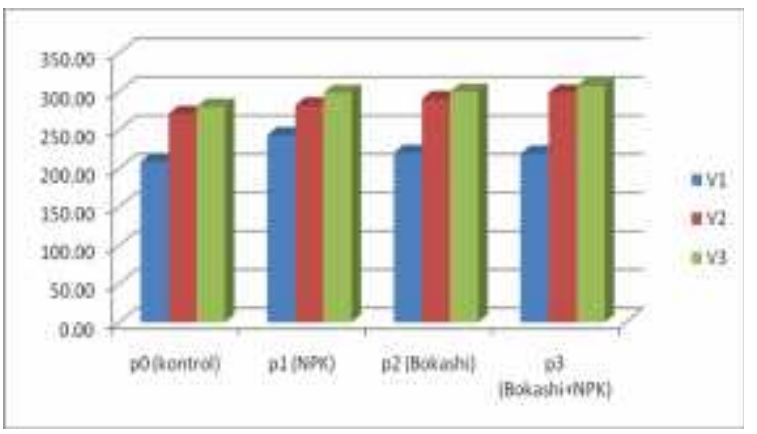

Gambar 1. Histogram pengaruh perlakuan pupuk Anorganik (p1-NPK), organik (p2Bokashi) dan kombinasinya (p3anorganik + organik) terhadap tinggi tanaman pada tiga varietas $\mathrm{v} 1$ (Lokal), v2 ( Darul Hidayah) dan v3 (Gajah) ubi kayu.

Dari hasil analisis statistik (Tabel 5) pada berat umbi per hektar menunjukkan bahwa pupuk anorganik (p1)menghasilkan 124 ton per hektar dan organik (p2) 130,44 ton per hektar serta kombinasinya(p3) 134,67 ton/hektar berpengaruh nyata dibandingkan dengan kontrol(p0) yaitu 99,11 ton/hektar pada semua varietas, yaitu pemupukan anorganik NPK(P1), pupuk organic (P2) dan kombinasinya(P3) masing-masing lebih tinggi $20 \%, 23,8 \%$ dan 26,1\% dibandingkan kontrol(p0). Produksi umbi varietas Darul Hidayah (V2) 148,50 ton dan Gajah(V3) 132,33 ton sedangkan kontrol hanya 85 ton per hektar. Produksi ini lebih tinggi secara nyata masing-masing $42,5 \%$ dan $35,6 \%$ dibandingkan varietas lokal (V1) tetapi antara varietas Darul Hidayah (V2) dan Gajah (V3) tidak berpengaruh nyata meskipun Varietas Darul Hidayah lebih tinggi 16,17 ton per hektar (1\%) dibandingkan varietas Gajah. Hal ini disebabkan karena pemberian pupuk anorganik (NPK) akan menambah ketersediaan unsur hara

\section{Berat Biomasa( Batang + Daun ) Per Hektar}

Pengaruh perlakuan pupuk anorganik dan organik (bokashi) serta kombinasinya terhadap berat bomassa per hektar pada tiga varietas ubi kayu tercantum pada Tabel 7 . Hasil analisis

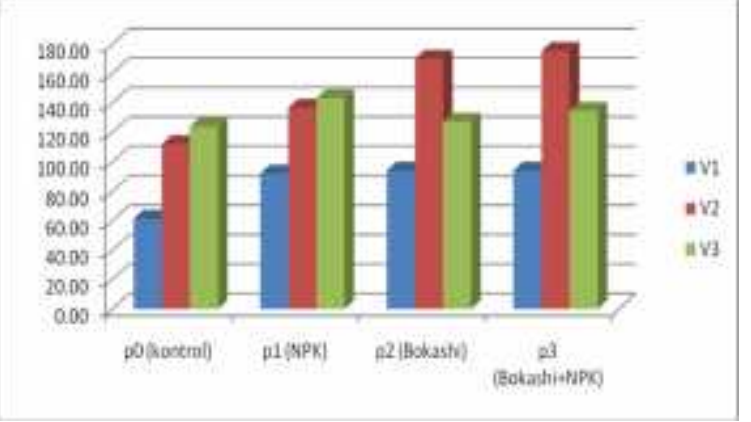

Gambar 2. Histogram pengaruh perlakuan pupuk Anorganik (p1-NPK), organik (p2-Bokashi) dan kombinasinya (p3anorganik + organik) terhadap berat umbi per hektar pada tiga varietas v1(Lokal), v2 ( Darul Hidayah) dan v3 (Gajah) ubi kayu.

dalam tanah. Ditambahkan oleh (Chen JenHshuan,2006), bahwa pupuk NPK lebih cepat direspon oleh tanah dan unsur hara lebih cepat tersedia bagi tanaman.sehingga memperbaiki sifat kimia tanah. Kemudian ditambah pupuk organik (bokashi) berarti fermentasi bahan organik dengan efektif organisme (EM) merupakan kultur campuran dari mikroorganisme yang menguntungkan sehingga membantu memperbaiki biologi tanah dan membantu penyerapan unsur hara tanah. Wididana (1993) menambahkan pupuk bokashi mengandung mikroorganisme fermentasi dan fotosintetik yang terdiri dari bakteri asam laktat(Lactobacillus sp, bakteri fotosintetik (Rhodo pseudomonas sp.), Actinomycetes sp., Streptomyces sp. dan ragi( yeast).(Wididana, dan Huga 1993).mempertegasdengan pemberian NPK dan bokashi mampu menambah asam amino, gula, ester, enzim, alcohol dan vitamin yang dibutuhkan tanaman ubi kayu. Akibatnya produksi ubi kayu meningkat.

statistik interaksi antara dosis pupuk dan varietas terhadap berat biomassa per petak tercantum pada Tabel 7 dan digambarkan dalam bentuk diagram batang (Gambar 3).

Tabel 6. Interaksi antara dosis dan varietas terhadap biomassa per hektar pada tiga varietas ubi kayu (ton/hektar)

\begin{tabular}{lcccc}
\hline \multicolumn{1}{c}{ Perlakuan Pemupukan } & v1 & v2 & v3 & Rata-rata \\
\hline p0 (kontrol) & 17,00 & 56,67 & 59,67 & $44,44 \mathrm{~b}$ \\
p1 (NPK) & 46,67 & 69,33 & 63,00 & $59,67 \mathrm{ab}$ \\
p2 (Bokashi) & 50,67 & 69,33 & 61,00 & $60,33 \mathrm{ab}$ \\
p3 (bokashi+NPK) & 64,00 & 81,00 & 75,00 & $73,33 \mathrm{a}$ \\
\hline \multicolumn{1}{c}{ Rata-rata } & $44,58 \mathrm{~b}$ & $69,08 \mathrm{a}$ & $64,67 \mathrm{a}$ & 59,44 \\
\hline
\end{tabular}

Keterangan : Angka yang diikuti huruf yang sama menyatakan tidak berbeda nyata pada BNT 5\% (BNT P = 16,29 dan BNT V = 12,20) 
Tabel 7. Pengaruh perlakuan pupuk anorganik dan organik serta kombinasinya terhadap berat biomasa per hektar ( ton )

\begin{tabular}{cccccc}
\hline \multirow{2}{*}{ Varietas } & Perlakuan & \multicolumn{3}{c}{ Kelompok (varietas) } & \multirow{2}{*}{ Total } \\
\cline { 3 - 5 } & pemupukan & 1 & 2 & 3 & \\
\hline \multirow{4}{*}{ v1(Lokal) } & p0(kontrol) & 11,00 & 22,00 & 18,00 & 51,00 \\
& p1(NPK) & 28,00 & 58,00 & 54,00 & 140,00 \\
& p2(bokashi) & 78,00 & 23,00 & 51,00 & 152,00 \\
& p3(Bokashi + NPK) & 67,00 & 57,00 & 68,00 & 192,00 \\
\hline \multirow{3}{*}{ v2(Darul } & p0(kontrol) & 50,00 & 64,00 & 56,00 & 170,00 \\
Hidayah) & p1(NPK) & 70,00 & 75,00 & 63,00 & 208,00 \\
& p2(bokashi) & 60,00 & 80,00 & 68,00 & 208,00 \\
& p3(Bokashi + NPK) & 111,00 & 73,00 & 59,00 & 243,00 \\
\hline \multirow{2}{*}{ v3(Gajah) } & p0(kontrol) & 57,00 & 75,00 & 47,00 & 179,00 \\
& p1(NPK) & 76,00 & 63,00 & 50,00 & 189,00 \\
& p2(bokashi) & 43,00 & 74,00 & 66,00 & 183,00 \\
Total & p3(Bokashi + NPK) & 84,00 & 63,00 & 78,00 & 225,00 \\
\hline
\end{tabular}

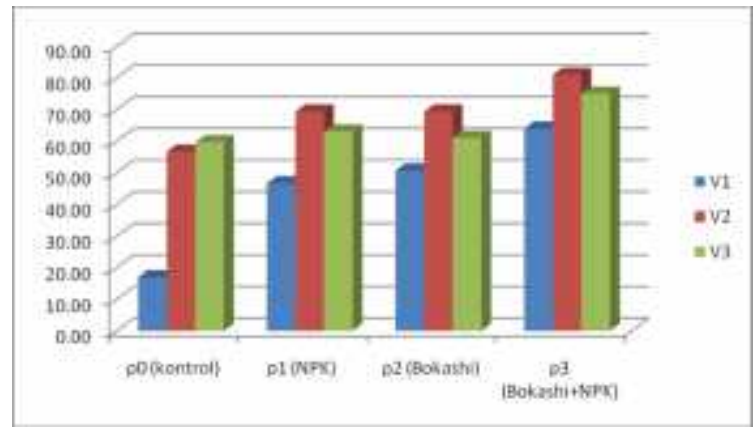

Gambar 3. Histogram pengaruh perlakuan Anorganik (p1-NPK), organik (p2-Bokashi) dan kombinasinya (p3- anorganik + organik) terhadap berat biomasa per hektar pada tiga varietas v1(Lokal), v2 (Darul Hidayah) dan v3 (Gajah) ubi kayu

Hasil analisis statistik ( Tabel 6 dan 7 ) pada berat biomassa per hektar menunjukkan bahwa pupuk anorganik (p1) dan organik (p2) tidak berpengaruh nyata dibandingkan kontrol, sedangkan kombinasinya (p3) berpengaruh nyata dibandingkan dengan kontrol (p0) pada semua varietas. Pupuk anorganik NPK(p1), pupuk organik (p2) dan kombinasinya (p3) masingmasing lebih tinggi $27 \%, 40 \%$ dan $36 \%$ dibandingkan kontrol (p0). Antara varietas yaitu Darul Hidayah (v2) dan Gajah(v3) lebih tinggi secara nyata masing-masing $36 \%$ dan $31 \%$ dibandingkan varietas lokal (v1) tetapi antara varietas Darul Hidayah (v2) dan Gajah (v3) tidak berpengaruh nyata. Dengan pemberian pupuk mengandung unsur-unsur NPK yang dibutuhkan oleh tanaman ubi kayu sangat berpengaruh terhadap pertumbuhan dan perkembangan produksinya, unsur $\mathrm{N}$ dibutuhkan tanaman untuk pertumbuhan vegetatif yang sangat berkolerasi dengan meningkatnya pertumbuhan maka akan meningkatkan produksi, Unsur P berperan untuk merangsang perakaran, sehingga dengan banyaknya perakaran maka jumlah umbi bertambah, selanjutnya unsur $\mathrm{K}$ sangat dibutuhkan untuk pembentukan umbi pada tanaman ubi kayu. Akibatnya dengan pemberian unsur hara yang cukup maka pertumbuhan dan pembentukan umbi meningkat pula.

\section{KESIMPULAN}

Berdasarka hasil-hasil analisis dan pembahasan dapat disimpulkan sebagai berikut :

1. Pemupukan anorganik (NPK), organik (bokashi) dan kombinasinya mampu menghasilkan umbi masing-masing 124 ton/hektar, 130,44 ton per hektar dan 134,67 ton/hektar, sedangkan kontrol 99,11 ton/hektar atau perlakuan pemupukan tersebut dapat meningkatkan produksi umbi masing-masing $20 \%, 23,8 \%$ dan $26 \%$ dibandingkan kontrol. Antara pemupukan anorganik (NPK), organik(bokashi) dan kombinasinya (NPK + organik) tidak berbeda nyata.

2. Produksi umbi antara varietas Darul Hidayah (V2) dan Gajah ( V3) masingmasing beratnya 148,50 ton per hektar dan 132,33 ton per hektar menunjukkan perbedaan nyata dibandingkan dengan varietas Lokal yang beratnya 85,33 ton per hektar. Masing-masing varietas tersebut berat umbinya lebih tinggi 42,5\% dan 35,6\% dibandingkan varietas Lokal. Sedangkan antara Darul Hidayah dan Gajah tidak berbeda nyata. 


\section{DAFTAR PUSTAKA}

Arifin. 2005. Kandungan Gizi Pada Ubi Kayu. Jurnal Ilmiah Ilmu-ilmu Peternakan.

Arinong, AR., Lasiwa, C.D. 2011. Aplikasi Pupuk Organik Cair Terhadap Pertumbuhan Dan Produksi Tanaman Sawi. Jurnal agrisistem 7(1); 47-54

Chen Jen-Hshuan. 2006. The Combined Use of Chemical And Organik Fertilizers And Or Biofertilizers For Crop Growth And Soil Fertility. International Workshop on Sustained Management of the Soil-Rhizosphere System for Efficient Crop Production and Fertilizer Use Land Development Department, Bangkok 10900 Thailand,.

Hadi Suwito, S. 2007. Membuat Pupuk Kompos Cair. PT. Agro Media Pustaka, Jakarta.

Kymaryo, V.M., G. A. Massawe, N. A. Olasupo, W. H. Holzapfel. 2000. The Use Of Stater Culture In The Fermentation Of Cassava For The Production Of "Kivunde", Aa Traditional Tanzanian Food Product. Int. J. of Food Microb. 56: 179-190.

Novizan. 2005. Petunjuk Pemupukan Yang Efektif. Agromedia Pustaka. Jakarta

Nurhayati Hakim, Y. Nyakpa, A.M. Lubis, S.G. Nugroho, M.R. Saul, M.A. Diha, G.B. Hong, dan H. Bailey. 1986. Dasar-
Dasar Ilmu Tanah. Universitas Lampung, Lampung.

Radjit, B.S. dan N, Prasetiaswati. 2011. Hasil Umbi dan Kadar Pati Pada Beberapa Varietas Singkong. J. Agrivigor. Volume 10(2): 185-195.

Rosmarkum, A. dan N.W. Yuwono. 2002. Ilmu Kesuburan Tanah. Kanisius. Yogyakarta.

Setyamidjaya, D. 1986. Pupuk dan Pemupukan. Simplek, Jakarta.

Setyorini, Diah. 2005. Pupuk Organik Tingkatkan Produksi Pertanian. Warta Penelitian dan Pengembangan Pertanian. Balai Penelitian Tanah, Bogor. 06 (VII).

Stevenson FJ. 1982. Humus Chemistry: Genesis, Composition. Raction. John Willey. New York

Wididana, G.N. dan T. Higa. 1993. Penuntun Bercocok Tanam Padi dengan Teknologi dengan Teknologi Effective Microrganism -4 (EM-4). Seri Pertanian Akrab Lingkungan.

Wididana, G.N. 1993. Peranan Effective Microorganism-4 dalam Meningkatkan Kesuburan dan Produktivitas Tanah. Indonesia Kyusei Nature Farming.

Yi Bo, Lifei Hu, et al. 2010. Antioxidant Phenolic Compounds of Cassava (Manihot esculenta) from Hainan. Molecules, 16:10157- 10167 